\title{
HYBRID COMPOSITE CABLE FOR PRESTRESSED SUSPENSION STRUCTURE
}

\author{
Vadims Goremikins $^{1}$, Karlis Rocens ${ }^{2}$, Dmitrijs Serdjuks ${ }^{3}$, Raimonds Ozolins ${ }^{4}$, Girts Frolovs ${ }^{5}$ \\ 1,2,3,4,5 Institute of Structural Engineering and Reconstruction, Faculty of Civil Engineering, Riga Technical University, \\ Azenes Str. 16/20, LV-1048 Riga, Latvia

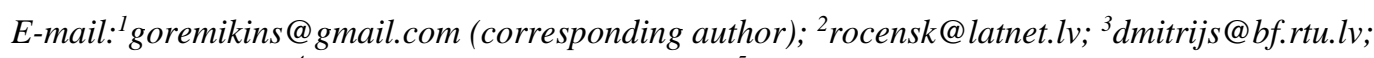 \\ ${ }^{4}$ raimonds.ozolinsh@apollo.lv; ${ }^{5}$ girts.frolovs@gmail.com
}

\begin{abstract}
A prestressed suspension structure is a type of structures that allows covering long spans due to rational use of structural materials. Prestressing of a suspension structure allows minimizing cinematic displacements. The prestressed suspension structure with the main span equal to $200 \mathrm{~m}$ was considered as an object of investigation. Replacement of a single steel main cable of the prestressed suspension structure by the hybrid composite cable with CFRP (Carbon Fibre Reinforced Polymer) middle layer and external steel layers with cross-section variable by the cable length considerably decreases dead weight of the cable. Hybrid composite cable ensures functioning of the structure in case of destruction of the middle CFRP layer. The considered prestressed suspension structure was investigated by the FEM software ANSYS. Rational steel distribution by the cable length was determined by optimization. Behaviour of the hybrid composite main cable in the case of destruction of the middle CFRP layer was experimentally tested using the physical model. The dynamic coefficient was obtained.
\end{abstract}

Keywords: experimental model, dynamic coefficient, cable truss, CFRP

\section{Introduction}

Suspension cable structures are structures, where the deck is continuously supported by stretched catenary cable (Chen, Lui 2005). Suspension structures are the most important and attractive structures possessing a number of technical, economical and aesthetic advantages (Grigorjeva et al. 2010).

At the present moment, a suspension cable structure is the most suitable type of structure for very long-span bridges. Such long spans can be constructed because the main load carrying cables are subjected to tension, and distribution of normal stresses is close to uniform (Juozapaitis et al. 2010).

Increased deformability is one of the basic disadvantages of suspension structures (Walther et al. 1999). Increased deformability is conditioned by the appearance of elastic and kinematic displacements. Elastic displacements are caused by large tensile inner forces. Elastic displacements are maximal at the centre of the span in the case of symmetrical load application. Kinematic displacements are caused by initial parabolic shape change, resulting from non-symmetrical or local loads (Fig. 1) (Juozapaitis, Norkus 2004). These displacements are not related to elastic characteristics of the cable. Serviceability limit state dominates for suspension cable structures.

Elastic displacements can be reduced by applying low strength steel structural profiles, reinforced concrete and by increasing elastic modulus and cable camber (Kirsanov 1973).

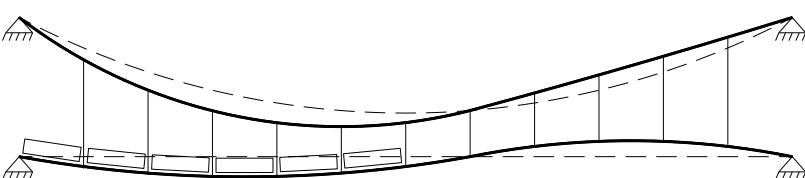

Fig. 1. Initial shape change under the action of non-symmetrical load.
The problem of increased kinematic displacements can be solved by adding of cantledge, by increasing girder stiffness and main cable camber, by connecting the main cable and girder at the centre of the span, by applying diagonal suspenders or inclined additional cables, two chain systems or stiff chains, and stress ribbons (Kachurin et al. 1971). Nevertheless, these systems are characterized by material consumption increase, and system stiffness is not sufficient in many cases.

Usage of a prestressed cable truss is another method of fixing the problem of increased kinematic displacements under the action of unsymmetrical load (Serdjuks, Rocens 2004; Goremikins et al. 2011). Different types of cable trusses are known, such as convex cable trusses, convexconcave cable trusses, cable trusses with centre compression strut or parallel cable trusses (Schierle 2012). However, one of the most efficient and convenient for application is a concave cable truss (Fig. 2). Usage of cable trusses allows for the construction of bridges with reduced requirements for girder stiffness, but overall bridge rigidity will be ensured by prestressing of stabilization cable (Goremikins et al. 2012a). The deck can be made of light composite materials (Goremikins et al. 2010a).

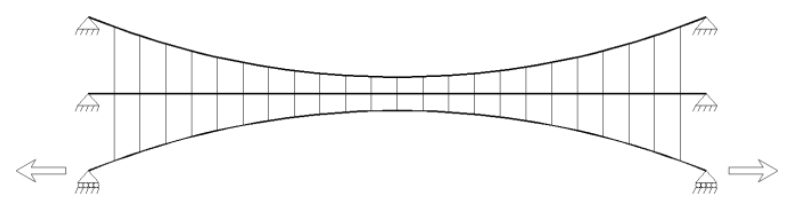

Fig. 2. Stabilization of suspension bridge by prestressing.

High-strength materials, such as FRCC and FRP, have a potential for their application as structural materials in combination with steel (Serdjuks, Rocens 2003; Goremikins et al. 2010b). Carbon fibre reinforced plastic (CFRP), glass fibre reinforced plastic (GFRP) and Vectran are examples of such materials. As structural materials, they have the following advantages: high specific strength, which allows increasing the span of 
suspended structures several times; good durability in aggressive environment; magnetic or electric nonconductivity; low density (Serdjuks, Rocens, Pakrastins 2008).

However, CFRP, GFRP and Vectran have a number of disadvantages, which limit their application as structural materials. Small elongation at break, poor characteristics perpendicular to grains, probability of surface damages, difficulties in connection of suspenders are most significant disadvantages of CFRP, GFRP and Vectran in comparison with steel cables (Serdjuks, Rocens, Pakrastins 2008).

Small elongation at break significantly decreases the safety of construction due to probability of brittle failure during a short-time growing of the load. This disadvantage could be offset by adding some steel component, which would increase cable reliability. The hybrid composite tensioned elements can be created on the basis of separate bands joined together (Fig. 3) (Serdjuks, Rocens, Pakrastins 2008).

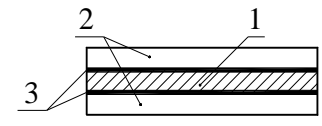

Fig. 3. Cross-section of hybrid composite cable. 1 - CFRP band; 2 - steel bands; 3 - glue.

The aim of this research is to develop the structure of hybrid composite cable for prestressed cable structure rational from the point of view of material consumption and to check analytically and experimentally the safety of the structure in case of CFRP layer destruction.

\section{Description of the Investigation Object}

Prestressed suspension structure with a span of $200 \mathrm{~m}$ (Fig. 4.) was considered as the investigation object (Goremikins et al. 2012e). Camber of the main cable is equal to $1 / 10$ from the span or $20 \mathrm{~m}$, camber of the stabilization cable is equal to $1 / 20$ from the span, or $10 \mathrm{~m}$.

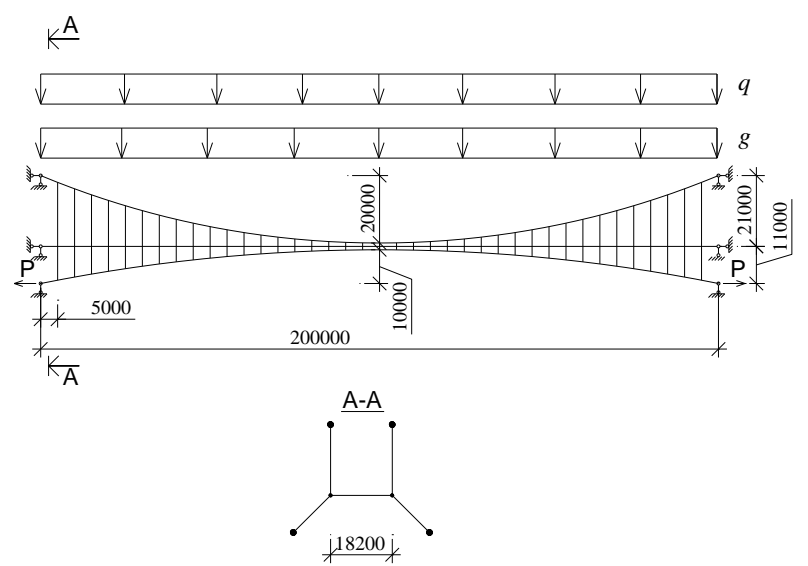

Fig. 4. Design scheme of the prestressed suspension structure.

The structure is loaded by dead weight, equal to $82.2 \mathrm{kN} / \mathrm{m}$ and imposed load, equal to $82.2 \mathrm{kN} / \mathrm{m}$ (Goremikins et al. 2012c). The structure is prestressed. The prestressing level is equal to $60 \%$ of the main cable load bearing capacity (Goremikins et al. 2012b).
The main cable of the prestressed suspension structure is made from hybrid composite cable, which consists of middle CFRP layer and external steel layers. This cable structure allows minimizing the dead weight and material consumption of the structure and ensuring the safety of the structure in case of CFRP layer destruction.

As the distribution of internal forces along the cable is not uniform, it is rational to develop a cable with a varied cross-section area of steel layers by cable length, which allows minimizing material consumption (Fig. 5).

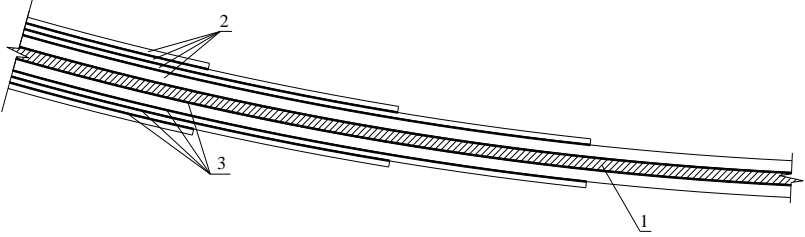

Fig. 5. Hybrid composite cable with various cross-section area of steel layers by cable length. 1 - CFRP layer; 2 - steel layer; 3 -glue.

As internal forces are not uniform along cable length, but they are equal in the section between suspensions, the cable was divided into 40 sections, which were bounded by suspensions. The numeration of sections is from the centre of the cable to the edges, starting with 0 -section (Fig. 6). The cross-section area of steel layers in each section differs (Goremikins 2013).

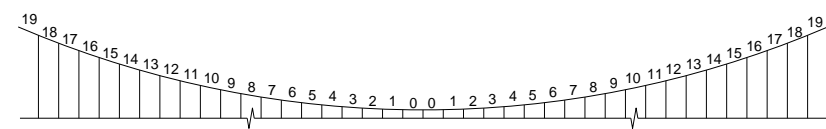

Fig.6. Division of the main cable to sections.

As the disadvantage of suspended cable structures is large deformations, ultra high modulus CFRP (ePLATE HM512, Mitsubishi Plastics Composites America, Inc.) (Peris 2011) was selected for the middle layer of the cable to minimize elastic displacements. Characteristics of the material are given in Table 1 .

Table 1. Characteristics of CFRP with ultra-high elastic modulus

\begin{tabular}{|l|l|l|}
\hline $\begin{array}{l}\text { Tension Elastic } \\
\text { Modulus, GPa }\end{array}$ & $\begin{array}{l}\text { Tension Strength, } \\
\text { MPa }\end{array}$ & Ultimate Strain \\
\hline 514 & 1923 & 0.00332 \\
\hline
\end{tabular}

Steel with S450 class was selected as the material for external layers of the cable (LVS EN 10025-2: 2005). Characteristics of the material are given in Table 2 . Bilinear with strain hardening steel behaviour model was selected. Stress-strain curves of the materials are shown in Fig. 7. 
Table 2. Characteristics of Steel S450

\begin{tabular}{l|c}
\hline Yield strength, $f_{y}, \mathrm{MPa}$ & 440 \\
Ultimate strength $f_{u}, \mathrm{MPa}$ & 550 \\
Modulus of elasticity in elastic stage, $\mathrm{MPa}$ & 210000 \\
Modulus of elasticity in plastic stage, $\mathrm{MPa}$ & 800 \\
Strain at yield point & 0.002 \\
Ultimate strain & 0.14 \\
\hline
\end{tabular}

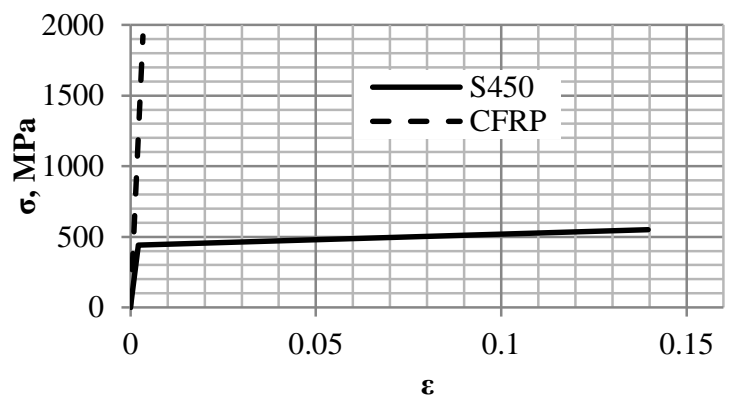

Fig. 7. Stress-strain curves of ultra-high modulus CFRP and Steel S450. $\sigma-$ stress; $\varepsilon-$ strain.

The materials were specially selected to ensure that steel layers provide CFRP with the required plastic deformations due to the proper selection of the ultimate strains of the material.

\section{Determination of Rational Cross-Section Area of Layers}

Distribution of internal forces along cable length of the suspended structure, as well as distribution of the stresses in case of constant cross-section area can be described with the second order polynomial. In this connection, the cross-section area of the steel layers at each section is described by the second order polynomial (1):

$$
A_{\text {steel, } i}=c+b \cdot i+a \cdot i^{2},
$$

where $i$ - section number, count from the middle part $(i=0 \div 19)$;

$A_{\text {steel, } i}$ - cross-section area of steel at $i$ section;

$c, b, a$-coefficients of equation, which are selected as variable factors.

The cross-section area of CFRP layer is described as a part of the steel cross-section area at 0 section (2).

$$
A_{C F R P}=d \cdot A_{\text {steel }, i=0},
$$

where $A_{\text {steel, } i=0}$ - cross-section area of steel at 0 section; $A_{C F R P}$ - cross-section area of CFRP layer;

$d$ - coefficient of CFRP cross-section area, variable factor of optimization.

The aim of optimization was to minimize the difference between the stresses in the cable and the allowed stresses (3), ensure maximum application of CFRP and ensure displacements on the level of $10 \mathrm{~m}$ in the case of middle CFRP layer destruction during shorttime increase of the load, which allows the structure to function in emergency conditions. Variable factors of optimization are coefficients $a, b, c, d$. $\left([\sigma]-\sigma_{i}\right) \rightarrow 0$

where $[\sigma]-$ allowed stresses (4);

$\sigma_{i}-$ stresses in $i$ section.

$[\sigma]=f_{y}-1 \mathrm{MPa}=339 \mathrm{MPa}$.

In case of destruction of the middle layer, all internal forces will be carried out by steel layers, stresses in the steel layers exceed the yield point and steel begins to yield. Camber of the main cable begins to increase but the level of prestressing begins to fall, so internal forces in the main cable decrease and then the process of steel yield stops at the defined level. It was assumed that if CFRP layer destructs in one place of the cable, it will be totally excluded from the cable work (Sliseris, Rocens 2010).

The optimization was realized by Genetic algorithm and enumerative method using MatLAB and ANSYS software (Sliseris et al. 2013; Goremikins et al. 2013b). Steel layer behaviour was modelled with bilinear material model in ANSYS (TB, BISO function). Rational characteristics were determined (5), (6). Changes of internal forces in case the middle CFRP layer is either broken or unbroken are shown in Fig. 8. With cable rational characteristics, the stresses in the steel layers of the cable in case CFRP layer is unbroken are from 438.2 $\mathrm{MPa}$ to $439.8 \mathrm{MPa}$, smaller than the steel yield strength. Stresses in the CFRP layer are 1,076.5 MPa, smaller than CFRP tensile strength. In case of CFRP middle layer destruction, after steel yielding internal forces in the cable decrease up to $71.5 \%$, stresses in the steel layers are from 450.7 to $468.8 \mathrm{MPa}$, smaller than steel ultimate stress, and the structure can last to ensure evacuation.

$$
\begin{aligned}
& A_{\text {steel }, i}=0.002798+0.0000824 \cdot i+0.0000194 \cdot i^{2}, \\
& A_{C F R P}=1.0978 \cdot A_{\text {steel }, i=0} .
\end{aligned}
$$

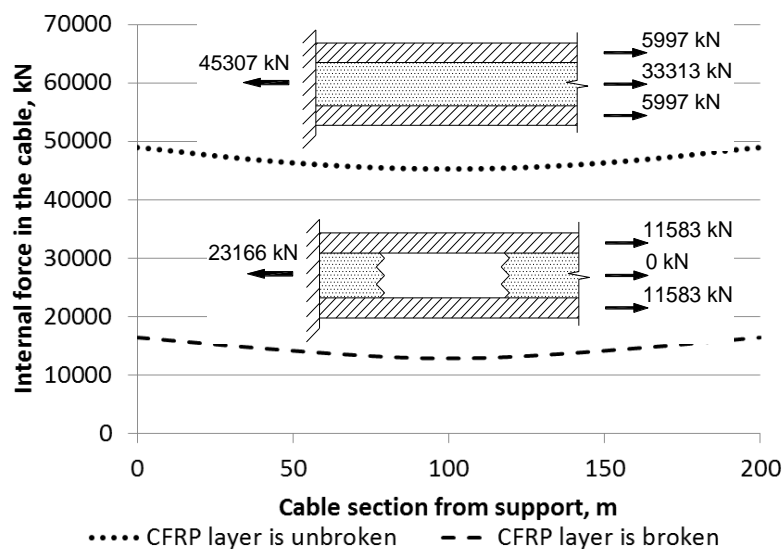

Fig. 8. Distribution of internal forces in the cable.

When CFRP layer is destructed, dynamic effects can influence the behavior of the structure. Taking into account the dynamic influence by coefficients ( $\Phi=1.24$ for imposed load and $\Phi=2$ for dead weight 
(Eurocode 1, Part 2: 2004; Goremikins et al. 2013a), rational coefficients for the cable were determined: $a=0.00002068 \mathrm{~m}^{2} ; b=0.00006958 \mathrm{~m}^{2} ; c=0.04416 \mathrm{~m}^{2}$; $d=0.5395$. Taking into account dynamic influence, the steel area should be increased by $58 \%$, but the CFRP area should be decreased two times.

\section{Experimental Analysis of Cable Behaviour in Case of CFRP Layer Destruction}

Experimental model of the steel band cable was developed (Fig. 9) to model the situation, when the CFRP layer was destructed. The span of the model is equal to $1.7 \mathrm{~m}$, camber of the cable is equal to $0.17 \mathrm{~m}$. Width and thickness of the cross-section of the cable is 13 and $1 \mathrm{~mm}$, respectively. The load is applied in points with step $0.17 \mathrm{~m}$. As the structure models the situation of cable behaviour in case of CFRP layer destruction, the load should be applied instantly. It was realized by knockingout props. The load was selected in such a way that the material worked in the plastic stage. The total load at each point was equal to $380 \mathrm{~N}$. The design scheme of the experimental model of the cable is shown in Fig. 10. The material of the cable is DC01 steel. The characteristics of the steel are given in Table 3. Experimentally obtained stress-strain curve of DC01 steel is shown in Fig. 11.

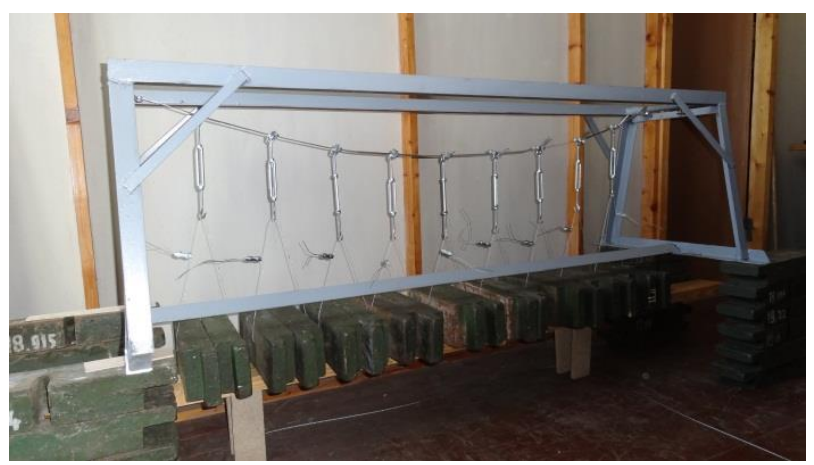

Fig. 9. Experimental model of the cable.

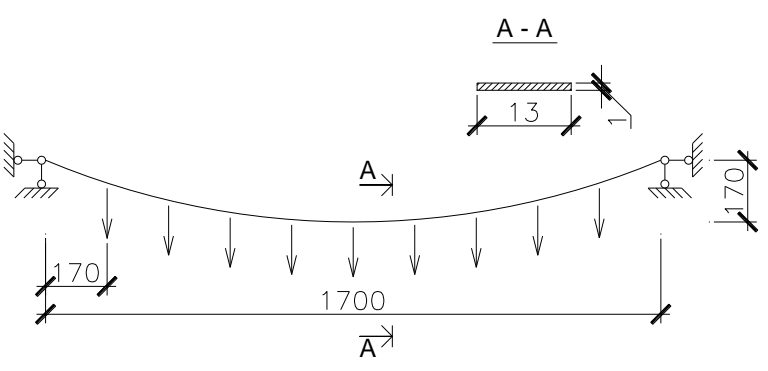

Fig. 10. Design scheme of the experimental model of the cable.

Table 3. Material characteristics of steel layer (DC01)

\begin{tabular}{l|l|l}
\hline $\begin{array}{l}\text { Yield strength, } f_{y}, \\
\mathrm{MPa}\end{array}$ & $\begin{array}{l}\text { Ultimate strength } \\
f_{u}, \mathrm{MPa}\end{array}$ & Ultimate strain \\
\hline 216 & 336 & 0.35 \\
\hline
\end{tabular}

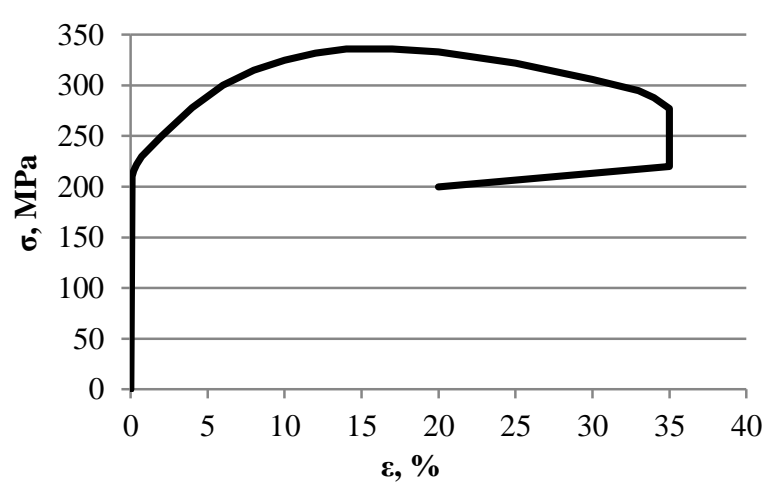

Fig. 11. Stress-strain curve of DC01 steel.

The displacement of the middle point of the model after load application was $100 \mathrm{~mm}$. The model sustained instantly applied load (Fig. 12). Vibrations of the model were observed.

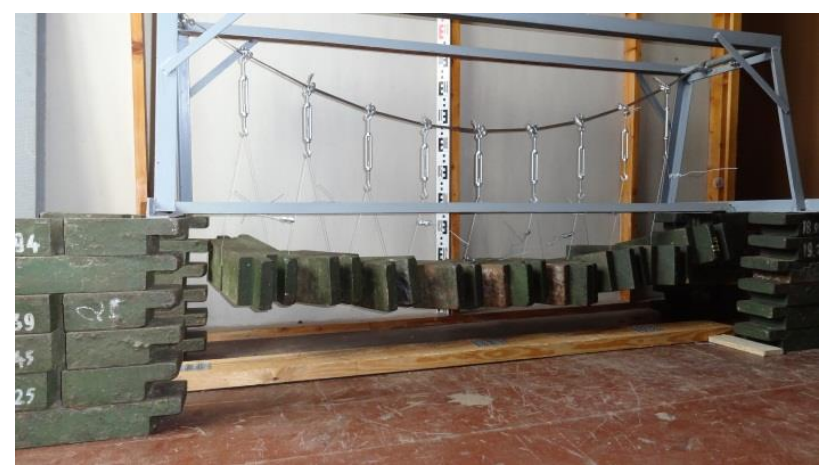

Fig. 12. The model after the moment of instant application of the load.

The behavior of the model was compared with the one numerically calculated by ANSYS. The behavior of steel band was modelled by multilinear material model (TB, MELA function).

Displacement of the middle point of the model numerically obtained by ANSYS program is equal to $75.1 \mathrm{~mm}$, maximal stresses are equal to $277.7 \mathrm{MPa}$.

If the assumed material behavior is linear throughout the stage, then in the case of application of $380 \mathrm{~N}$ load, the displacement of the middle point will be equal to $5.7 \mathrm{~mm}$ but stresses will be equal to $376 \mathrm{MPa}$.

As the dynamic effects were observed, the dynamic coefficient was obtained by equation (7) and it is equal to 1.33 .

$K_{D}=\frac{\delta_{\text {din }}}{\delta_{s t}}$

where $\delta_{\text {din }}$ - dynamic displacements;

$\delta_{s t}-$ static displacements.

\section{Conclusions}

Replacement of the single steel main cable of a prestressed two-chord cable structure by the hybrid composite cable with CFRP (Carbon Fibre Reinforced Polymer) middle layer and external steel layers with 
cross-section variable by the cable length considerably decreases the dead weight of the cable. In the case of static load and $200 \mathrm{~m}$ span, the dead weight is decreased three times. Rational distribution of steel along the cable length, which provides practically uniform stress distribution in cable components by length is one of the reasons of the decrease of the dead weight. Furthermore, the structure of the cable ensures functioning of the structure in case of destruction of the middle CFRP layer. In this case the camber of the main cable instantly increases, but internal forces decrease due to steel yielding.

Rational steel distribution by the cable length was evaluated in the form of the second order polynomial and coefficients of the polynomial were determined by the genetic algorithm.

Cross-section area of the steel layer should be increased by $58 \%$ and cross-section area of CFRP layer should be decreased twice in case the dynamic effects are taken into account comparing with the static load.

The dynamic effects were observed on the experimental model in the case of instantly applied load. The dynamic coefficient is equal to 1.15 .

\section{References}

Chen, W. F.; Lui, E. M., 2005. Handbook of structural engineering. New York: CRC Press. 625 p. Available at: http://dx.doi.org/10.1201/9781420039931

Eurocode 1: Actions on structures. Part 2: Traffic loads on bridges. Brussels, 2004. $162 \mathrm{p}$.

Goremikins, V., 2013. Rational Large Span Prestressed Cable Structure. Doctoral Thesis. Riga: RTU. 155 p.

Goremikins, V.; Rocens, K.; Serdjuks, D.; Sliseris, J., 2013a. Simplified Method of Determination of Natural-Vibration Frequencies of Prestressed Suspension Bridge. Procedia Engineering, 57, pp. 343-352. Available at: http://dx.doi.org/10.1016/j.proeng.2013.04.046

Goremikins, V.; Rocens, K.; Serdjuks, D., 2013b. Topology Optimization of Cable Truss Web for Prestressed Suspension Bridge. World Academy of Science, Engineering and Technology, 73, pp. 41-47.

Goremikins, V.; Rocens, K.; Serdjuks, D., 2012a. Decreasing Displacements of Prestressed Suspension Bridge. Journal of Civil Engineering and Management, 18(6), pp. 858-866. Available at: http://dx.doi.org/10.3846/13923730.2012.720936

Goremikins, V.; Rocens, K.; Serdjuks, D., 2012b. Decreasing of Displacements of Prestressed Cable Truss. World Academy of Science, Engineering and Technology, 63, pp. 554-562.

Goremikins, V.; Rocens, K.; Serdjuks D., 2012c. Cable Truss Analyses for Suspension Bridge. In Proc. of $10^{\text {th }}$ International Scientific Conference "Engineering for Rural Development", 24-25 May, 2012, Jelgava, Latvia, 11, pp. 228-233.

Goremikins, V.; Rocens, K.; Serdjuks, D., 2012d. Analysis of Hybrid Composite Cable for Prestressed Suspension Bridge, In Proc. of the 17th International Conference „Mechanics of Composite Materials”, 28 May-1 June, 2012, Riga, Latvia, pp. 93.

Goremikins, V.; Rocens, K.; Serdjuks, D., 2011. Rational Structure of Cable Truss. World Academy of Science, Engineering and Technology, 76, pp. 571-578.
Goremikins, V.; Rocens, K.; Serdjuks, D., 2010a. Rational Large Span Structure of Composite Pultrusion Trussed Beam. Scientific Journal of RTU. Construction Science, 11, pp. 26-31.

Goremikins, V.; Rocens, K.; Serdjuks, D., 2010b. Rational Structure of Composite trussed beam, In Proc. of the $16^{\text {th }}$ international conference ,Mechanics of Composite Materials", 24-28 May, 2010, Riga, Latvia, pp. 75.

Grigorjeva, T.; Juozapaitis, A.; Kamaitis Z., 2010. Static analyses and simplified design of suspension bridges having various rigity of cables. Journal of Civil Engineering and Management, 16(3), pp. 363-371. Available at: http://dx.doi.org/10.3846/jcem.2010.41

Juozapaitis, A.; $\quad$ Idnurm, S.; $\quad$ Kaklauskas, G.; $\quad$ Idnurm, J.; Gribniak, V., 2010. Non-linear analysis of suspension bridges with flexible and rigid cables. Journal of Civil Engineering and Management, 16(1), pp. 149-154. Available at: http://dx.doi.org/10.3846/jcem.2010.14

Juozapaitis, A.; Norkus, A., 2004. Displacement analysis of asymmetrically loaded cable. Journal of Civil Engineering and Management, 10(4), pp.277-284. Available at: http://dx.doi.org/10.1080/13923730.2004.9636320

Kachurin, V.; Bragin, A.; Erunov, B., 1971. Proektirovanie visjachih $i$ vantovyh mostov. Moskva: Transport. $280 \mathrm{p}$.

Kirsanov, M., 1973. Visjachie sistemy povyshennoj zhestkosti. Moskva: Strojizdat. $116 \mathrm{p}$.

LVS EN 10025-2: 2005. Hot rolled products of structural steels Part 2: Technical delivery conditions for non-alloy structural steels.

Peris, N. A., 2011. Steel Beams Strengthened with Ultra High Modulus CFRP Laminates. Doctoral Dissertation. Kentucky: University of Kentucky. 307 p.

Schierle, G. G., 2012. Structure and Design. San Diego: Cognella. $624 \mathrm{p}$.

Serdjuks, D.; Rocens, K.; Pakrastins, L., 2008. Hybrid Composite Cable with an Increased Specific Strength for Tensioned Structures. The Baltic Journal of Road and Bridge Engineering, 3(3), pp.129-136. Available at: http://dx.doi.org/10.3846/1822-427X.2008.3.129-136

Serdjuks, D.; Rocens, K., 2004. Decrease the Displacements of a Composite Saddle-Shaped Cable Roof. Mechanics of Composite Materials, 40(5), pp.675-684. Available at: http://dx.doi.org/10.1023/B:MOCM.0000047234.72813.2e

Serdjuks, D.; Rocens, K., 2003. Hybrid composite cable based on steel and carbon. Materials Science, 9(1), pp. 27-30.

Sliseris, J.; Frolovs, G.; Rocens, K.; Goremikins, V., 2013. Optimal Design of GFRP-Plywood Variable Stiffness Plate, Procedia Engineering, 57, pp.1060-1069. Available at: http://dx.doi.org/10.1016/j.proeng.2013.04.134

Sliseris, J.; Rocens, K., 2010. Curvature Analysis for Composite with Orthogonal, Asymmetrical Multi-Layer Structure. Journal of Civil Engineering and Management 16(2), pp. 242-248. Available at: http://dx.doi.org/10.3846/jcem.2010.28

Walther, R.; Houriet, B.; Isler, W.; Moia, P.; Klein, J.F., 1999. Cable Stayed Bridges. Second edition. London: Thomas Telford. $236 \mathrm{p}$. 